\title{
SALL4 Gene
}

National Cancer Institute

\section{Source}

National Cancer Institute. SALL4 Gene. NCI Thesaurus. Code C112905.

This gene plays a role in both transcriptional regulation and stem cell maintenance. 